\title{
GENITAL MUTILATION AS A CONSEQUENCE OF CRIMINAL OFFENCE AGAINST A PERSON
}

DOI: 10.36740/WLek202001122

\author{
Igor I. Mytrofanov' ${ }^{1}$ Igor V. Lysenko ${ }^{1}$, Kateryna V. Hryn ${ }^{2}$, Mykola M. Ryabushko ${ }^{2}$ \\ 'KREMENCHUK MYKHAILO OSTROHRADSKYI NATIONAL UNIVERSITY, KREMENCHUK, UKRAINE \\ ¿UKRAINIAN MEDICAL STOMATOLOGICAL ACADEMY, POLTAVA, UKRAINE
}

\begin{abstract}
The aim: The paper is aimed at creation of a procedure for determining the loss of any body organ or its functions, genital mutilation, as the signs of grievous bodily harm, penalty for which is stipulated by the Article 121 of the Criminal Code of Ukraine, as well as establishing the possibilities of legal setting of the concept of "genital mutilation". Materials and methods: Over 100 criminal proceedings, involving forensic medical examination, under the Article 121 of the Criminal Code of Ukraine for the period from 2007 to 19.05.2019 have been studied. Common methods of research have been used, namely, the analysis and synthesis, statistical method, as well as own observations of the process of judicial examination of the above criminal proceedings, as well as individual interviews, survey of the victims and their family members in total of 39 people.

Results and conclusions: The findings of the investigation enabled detecting the gaps in the regulation of the procedure to define genital mutilation as a characteristic feature of grievous bodily harm. The ways of further improvement of the procedure of conducting expert studies of genital mutilation as a characteristic feature of bodily harm, which facilitates avoiding of errors in forensic medical and judicial practices have been found. The process of criminalization of the illegal conduct of surgical operations, resulted in mutilation of genitalia, must take place with the mandatory involvement of specialists in the field of practical medicine, as well as medical scientists specializing in sexopathology, gynecology, oncogynecology, forensic medicine in order to avoid errors in the lawmaking.
\end{abstract}

KEY WORDS: genital mutilation, genital injury, bodily harm, grievous bodily harm, signs of grievous bodily harm, surgical operations caused genital mutilation, the procedure of genital mutilation identification

Wiad Lek. 2020;73(1):113-118

\section{INTRODUCTION}

Importantly, one of the main constitutional provisions is that human life and health is recognized as the highest value nationwide. That is why the Article 1 of the Criminal Code of Ukraine (hereinafter CC), developing the constitutional provisions, puts the human interests forward in the hierarchy of objects of criminal law. However, such legal foundation is not always effective in reduction of criminal activity related to offence against the life and health of a person. Thus, 38,274, 39,164 and 14,759 criminal offenses against life and health of a person were committed in 2017,2018 , and within three months of 2019, respectively. Among the offences against human life and health, special attention is given to the facts of offences causing grievous bodily harm (2058 cases in 2017; 2113 cases in 2018; 507 cases within three months of 2019), since in most cases they lead to the devastating damage to the health of a person, which in most cases resulted in disability of the victim.

Scientific researches and forensic medical practice carried out by domestic and foreign scientists have shown that, generally, the consequence of a criminal offence against victims' health is the loss of any body organ or its functions. Similarly, an examination of the adverse consequences of a criminal delinquency against the victim's health plays a significant legal role, which enables the authorities of the prejudicial inquiry and the court to assess correctly the actions of the defendants and establish the degree of their guilt in the presence of findings of properly conducted forensic examinations. In addition, the assessment of the severity of the damage to health caused by the criminal offence against the victim is a prerequisite for the implementation of a coherent program to protect the rights and interests of the victim. Such characteristic as the loss of any body organ or its functions, while determining the severity of bodily harm remains unclear to date (due to legal uncertainty) and the procedure for its determination is not well defined. Moreover, a new sign of grievous bodily harm as genital mutilation was defined in the CC of Ukraine in 11.01.2019. Consequently, it is uncertain whether the new interpretation is the equivalent of what existed before 11.01.2019, namely a loss of reproductive capacity, as a component of the concept "the loss of any body organ or its functions". However, the development of clear medical criteria for assessing bodily harm as grievous ones is relevant in contemporary forensic science.

The issues of legal regulation of setting punishment for causing bodily harm and the improvement of enforcement practice in this domain have been considered only fragmentarily in publications, devoted to criminal legal counteraction to bodily harm, problems on conducting forensic examinations in criminal proceedings, description of bodily harm. However, no scientific works related 
to solving problems of imposing penalty for the offence causing grievous bodily harm, resulted in the loss of any body organ or its functions, genital mutilation, made jointly by the criminologists and medical researchers have never been conducted, resulted in the terminological confusion in current legislation on both criminal liability and public health care. At the same time, investigation shows that the issues of identifying grievous bodily harm that caused the loss of any body organ or its functions, genital mutilation are complex, that is, are related to both medical and legal domain.

\section{THE AIM}

The paper is aimed at creation of a procedure for determining the loss of any body organ or its functions, genital mutilation, as the signs of grievous bodily harm, penalty for which is stipulated by the Article 121 of the CC of Ukraine, as well as establishing the possibilities of legal setting of the concept of "genital mutilation".

\section{MATERIALS AND METHODS}

To elucidate the issues that arise in forensic medical and judicial practice in determining the loss of any body organ or its functions as a characteristic feature of grievous bodily harm, over 100 criminal proceedings under the Art.121 of the CC of Ukraine for the period from 2007 up to the present time (19.05.2019 inclusively), which involved forensic medical examination to identify cases for evaluation of victims on the loss of any body organ or its functions, have been studied. For this purpose, common methods of research have been used, namely, the analysis and synthesis, statistical method as well as own observations of the process of judicial examination of the above criminal proceedings. Additionally, for the purpose of analyzing the perception of victims of crime and their physical condition, individual interviews and survey have been conducted. Respondents of the investigation were directly victims and their family members in total of 39 people and 18 forensic experts. The survey was also conducted among judges, investigators and prosecutors (hereinafter - lawyers) in total of 129 people to elucidate their opinion on the need for amendments to legislative acts on the statement of signs of grievous bodily harm.

\section{RESULTS}

Section 1 of the Article 121 of the CC of Ukraine established a penalty for intentional grievous bodily harm, i.e., intentional bodily harm, which caused the loss of any body organ or its functions, genital mutilation, liable for imprisonment for a term of five to eight years. In the 2001 CC of Ukraine no substitution was made for the category "bodily harm" to "damage to health", which is the key one for the investigated group of criminal delinquencies. At the same time, as it was mentioned above, on January 11, 2019 in the CC of Ukraine a new sign of grievous bodily harm as genital mutilation was introduced. The paragraph 2.1.4 of the Rules of Forensic Medical Examination on defining the degree of bodily harm severity, approved by the Order of the Ministry of Health of Ukraine No. 6 as of January 17, 1995 (hereinafter referred to as the Rules), establishes that non-life-threatening injuries that "belong to the grievous ones according to the end result and the consequences are: the loss of any body organ or its function, namely, loss of vision, hearing, the tongue, arm, legs and reproductive ability" [1].

Apparently, while introducing the above amendments to the CC of Ukraine, the lawmaker did not even take care of the problem of defining the concept of "genital mutilation", whether the above concept is identical to definition of the loss of reproductive capacity, whether it is absorbed by it fully or partially, or the loss of reproductive capacity remains a part of the concept "the loss of any body organ or its function". Admittedly, the MOH of Ukraine had enough time (since the adoption of the Law of Ukraine "On the amendments to the Criminal and Criminal Procedural Codes of Ukraine to implement the provisions of the Council of Europe Convention on preventing and combating violence against women and domestic violence" as of 06.12.2017 before commencement on 11.01.2019) to make corrections to the Rules, but did not do so.

Subparagraph "d" of the Paragraph 2.1.4 of the Rules stipulates that the "loss of reproductive capacity should be understood as the loss of ability to coitus or fertilize, conceive and childbearing (childbirth)" [1]. These issues are resolved in accordance with the provisions of the Rules for conducting forensic expert examinations concerning the sexual status at the Bureau of Forensic Medical Examination, approved by the Order of the Ministry of Health of Ukraine No. 6 dated January 17, 1995 (hereinafter referred to as the Rules on Sexual Conditions). Thus, according to par. 2.5 of the Rules on Sexual Conditions, the expert examination for the establishment of the ability to sexual intercourse and to fertilization in females is conducted jointly by the commission in cases on defining the severity of bodily harm in resolving issues of the loss of the ability to reproduction. Consequently, the expert should establish: a) in determining the ability to intercourse: absence of congenital defects and malformations of female genitalia or absence of vaginitis; $b$ ) in determining the ability to fertilize (in view of age and anatomical and physiological characteristics): absence of gynecological diseases (endometritis, tumors, malposition of the uterus, etc.), hormonal disorders, chronic infections and intoxications, radiation effects, etc. [2].

An expert examination of the ability to sexual intercourse in males is carried out jointly by the commission with the participation of a sexopathologist and conducting: a) a survey of the subject; b) examination of the subject; c) laboratory tests; d) study of the medical documentation and, if necessary, the materials of the case. The findings on the ability of the examined person to sexual intercourse should be based on the aggregate data of the survey, examination, laboratory tests, medical records and case materials, taking 
into account that the cause of sexual disorders could be severe exhausting general diseases, diseases of the central nervous system, inflammatory and other genital diseases, endocrine disorders, congenital defects (mutilation) of genitalia (e.g., prominent epi- or hypospadias), mechanical injury to the penis and the scrotum organs, and the presence of scarring and hardenings in the cavernous body, penis, lesions of the prostate (persistent lethargy, uneven tuberous surface, enlargement of one of the lobes, etc.) [2]. Thus, the Rules on Sexual Conditions consider the abnormality (mutilation) of genitalia as the reason for the loss of the ability of the subject to sexual intercourse (coitus).

The summary on the ability of the subject to fertilize should be based on the complex findings, considering the following: a) malformations of the penis (pronounced root or scrotal epi- and hypospadia) are not unconditional evidence of inability to fertilize; b) alterations in both testicles in the form of hardening and roughness (as a consequence of inflammatory process in the history) may be the cause of azoospermia, and such changes in one testicle only, while retaining the function of another, does not usually lead to loss of reproduction ability; c) detection of a bilateral hardening in the adnexa (as a consequence of inflammatory process or injury in the history), is usually an objective sign of inability to fertilize. The above cases can also occur in the unilateral lesion of the adnexa; d) pronounced scarring in the area of seminal vesicles and prostate (even in the absence of other lesions) can be a cause of azoospermia; e) from a forensic medical point of view, the presence of at least one normal spermatozoon in the ejaculate does not give grounds for assertion about the complete inability of the subject to fertilize. Notably, small number of spermatozoa (oligozoospermia) can only be indication of reduced, though not a complete, ability to fertilize [2].

It is obvious that the forensic and judicial practice of assessing the genital mutilation as the signs of bodily harm has not yet been formed, since little time have passed from the moment the relevant amendments to the CC of Ukraine were made; however, this cannot be a justification for developing the corresponding concept by the forensic medicine and criminal- legal science. Moreover, Article 38 of the Council of Europe Convention on Preventing and Combating Violence against Women and Domestic Violence (ETS No. 210, Istanbul Convention - hereinafter referred to as the Convention), recognized as the basic international document in the field of combating violence against women (Ukraine signed this Convention in 2011, though not ratified properly to date), provides for the prevention of female genital mutilation.

Article 38 of the Convention states that the "parties shall take the necessary legislative or other measures to ensure that the following intentional conducts are criminalized: a) excising, infibulating or performing any other mutilation to the whole or any part of a woman's labia majora, labia minora or clitoris; b) coercing or procuring a woman to undergo any of the acts listed in point a; c) inciting, coercing or procuring a girl to undergo any of the acts listed in point a" $[3, \mathrm{p} .67]$.
However, the lawmaker, introducing genital mutilation as the signs of grievous bodily harm, meant the acts listed in the Convention, that is, the deliberate injury, or female genital injury, or female genital mutilation, or female circumcision, or included into the concept of the male genital mutilation? The provisions of the Convention refer only to clitoridectomy, excision and infibulation (Pharaoh's circumcision). That is, it is about partial or total removal of the external female genitalia. When completely removed, the surface is closed by sewing or even binding the legs for several weeks, which eventually closes the opening to the vagina and the opening of the urethra, leaving only a small opening (sometimes no more than a matchhead) for natural needs. Such operations on female genitalia are considered by the World Health Organization as mutilation (mutilatio; lat. "circumcision", "shortening"), which is recognized as a violation of human rights $[4, \mathrm{p}$. 70].

The circumcision ritual is extremely harmful since it has negative outcomes, namely, 1) in more than $80 \%$ of cases it is carried out for girls from the first days of birth to 14-15 years old without any anesthesia and minimum hygiene; 2) it is mostly accompanied by severe bleeding, pain shock, wound infections, including tetanus and gangrene, or blood-borne infections such as HIV and Hepatitis $\mathrm{B}$ and C. Scarring, difficulty urinating, enuresis, menstrual disorders, multiple long lasting gynecological problems and other symptoms are the outcomes of mutilation. The UK National Health Service reports about a number of long-lasting health problems related to the outcomes of female genital mutilation, such as: 1 ) chronic vaginal and pelvic infections; 2 ) difficulty urinating, as well as persistent urinary tract infections; 3 ) renal failure; 4) dysfunction of the reproductive system, including infertility; 5) cysts and scar tissue formation; 6) complications during pregnancy and stillbirth; 7) pain during sexual contact and absence of a pleasant feeling; 8) psychological disorders, including low libido, depression and anxiety; 9) the need for further surgical intervention to open the vagina for sexual intercourse and childbirth [4, p. 70-71].

The World Health Organization reports about $18 \%$ of the female genital mutilation operations, carried out by healthcare professionals that raise serious concern about the fact that, actually, medical professionals violates the rights of women, undermining global efforts to eliminate such practices. Their participation provides this procedure not only with certain legitimacy, but also creates an idea of harmlessness or even health benefits [5].

However, the above considerations do not give us an answer to the question: what did lawmaker meant by the concept of "genital mutilation" as a sign of grievous bodily harm? The answer to this question is complicated by the fact that this sign was introduced into the Law of Ukraine "On the Amendments to the Criminal and Criminal Procedural Codes of Ukraine to implement the provisions of the Council of Europe Convention on Preventing and Combating Violence against Women and Domestic Violence" on 06.12.2017 and came into force on 11.01.2019. The limitation of the definition of genital mutilation only 
in the context of the Convention reduces its meaningful load. Moreover, the lawmaker does not indicate in the disposition of section 1 of the Article 121 of the CC of Ukraine on female genital mutilation, which is referred to in the provisions of the above Convention. We can conclude from the English version of the Convention that this is not a case of mutilation as such, but about the conduct of surgical procedures leading to female genital mutilation.

Moreover, the study shows, that in Ukraine, genital mutilation can occur both in women and men as a result of the effect of various factors (not only due to surgical procedures leading to mutilation), including hard and blunt objects with flat limited surface of the collision (fist, feet, stick, hammer, head of an axe, stone; about $85 \%$ of cases), as well as traffic accidents (more than 6,2\%), gunshot trauma (about $4,5 \%$ ), sexual intercourse $(1,3 \%)$, human teeth bite $(2.5 \%)$, circumcision in the understanding of the Convention $(0.001 \%)$.

Thus, in men, damage to the organs of the scrotum and the deep layers of the male external genital organs is recognized as characteristic of the transport, explosive and gunshot trauma, which are submucous hematomas, traumatic testicular dislocation, rapture of the testicular membranes and tissues, traumatic amputation of the penis and tear-contused wound. For example, a 33 year-old serviceman of the Armed Forces of Ukraine (hereinafter - the Armed Forces) K. have been exposed to numerous blows to the inguinal part of the body. He was reported about 6-7 minute-lasting loss of consciousness. The conservative treatment lasted for 15 days. In connection with growing scrotum swelling, surgical intervention was indicated as for the post-traumatic dropsy of right testicular (hydrocele). The postoperative period was complicated by post-traumatic orchiepididymitis (a combination of two diseases: inflammation of the testicle (orchitis) and epididymitis [6, pp. 144-147]. The patient recovered within 37 days, followed up with regular medical check-up due to the possible development of testicular atrophy and obstructive infertility. Moderate bodily harm was established on the basis of the duration of health disorder.

In the longer term, the complications of the follow up post-traumatic period, which obviously are manifested by the obstructive infertility, erectile dysfunction, can be seen in later life and when they occur, and the degree of bodily harm severity will be probably changed, which should be recorded by a forensic expert in the report. The issues of determining the degree of bodily harm severity in persons, who have been exposed to genital injury, judging by the resulting complications, occurred in the direct causal relationship with the trauma were not reflected even in the regulatory documents that regulate the procedure for determining the severity of bodily harm to a person. On the one hand, the injury itself is not so considerable (usually, bruising of the scrotum and hematoma of the testicles disappear within 3 weeks), but on the other hand a bruised area (concussion) of the testicle and its appendage affects the reproductive function. It is known that spermatogenous cells and epithelium are the most susceptible to injury, and, therefore, the disorder of spermatogenesis depends on the duration and degree of severity of circulatory disorders. Moreover, scrotal bruising, testicular hematoma can lead to fibrous degeneration of the tissue, and, when involved in the spermaduct process, to the persistent aspermia [ 7 , p. 14-17].

\section{DISCUSSION}

Apparently, introduction of the sign "genital mutilation" to section 1 of the Art.121 of the CC of Ukraine becomes even more unclear, since such mutilation can be assessed as not only the grievous bodily harm. In almost $50 \%$ of the situations, injury is accompanied by acute and subacute post-traumatic epididymitis and orchiepididymitis, which is consistent with the study conducted by other scientists [8] who believe that traumatic testicular trauma is always a post-traumatic orchiepididymitis, and to a lesser extent, excretory-obstructive infertility [9]. Bodily harm are defined as the grievous ones on the basis of loss of body organ (3\%); moderate bodily harm are defined on the basis of prolonged health disorders (3\%); minor bodily harm are defined on the basis of short-term health disorders (34\%); injuries were not considered as bodily harm(60\%). Formal approach to determining the severity of bodily harm in the genital trauma does not take into account the possibility of the follow-up shocking reaction at the time of injury, and post-traumatic complications, the occurrence of which covers a sufficiently long period of time [7, p. 16].

V.A. Mozgova, after studying the provisions of the Convention and finding out the extent of the incidence rate of female genital mutilation (according to the UN, each year, parents put at risk 3,000,000 girls, estimating as more than 8,000 a day, for the purpose of female genital mutilation), has proposed the following amendments to the section 2 of the Criminal Code of Ukraine: "Article 121-1. Female genital mutilation:

1. A person is guilty of an offence if he/she abets a girl to excise, infibulate (re-infibulate) or performing any other mutilation to the whole or any part of her own labia majora, labia minora or clitoris and is liable for imprisonment for a term up to three years.

2. A person is guilty of an offence if he/she coerces a girl to excise, infibulate (reinfibulate) or performing any other mutilation to the whole or any part of her own labia majora, labia minora or clitoris and is liable for imprisonment for a term up to five years.

3. The acts under sections 1 or 2 of the Article committed by a close relative or a family member of a person shall be punishable by imprisonment for a term of three to five years.

4. The acts of excision, infibulation (reinfibulation) or performing any other mutilation to the whole or any part of girl's own labia majora, labia minora or clitoris regardless of her consent, shall be punishable by imprisonment for a term of five to ten years.

5. The act under section 4 of the Article, committed against a minor or incapacitated person, or repeatedly, or if 
these acts have caused serious consequences, shall be punishable by imprisonment for a term of eight to twelve years.

6 . The acts under section 4 of the Article, committed against a minor, or with respect to two or more persons, or close relatives or family member of a person, or if these actions caused death of a person, shall be punishable by imprisonment for a term of ten to fifteen years.

7. A citizen of Ukraine or a person permanently residing on the territory of Ukraine is guilty of an offence if he/she coerces a girl to be infibulated (reinfibulated) or otherwise mutilated the whole or any part of girl's own labia majora, labia minora or clitoris outside Ukraine and is liable for imprisonment for a term from three to five years" [4, p. 75-76].

In connection with the controversy of the introduction of the analyzed amendments to section 1 of the Art.121 of the CC of Ukraine the search for adaptation of the norms of the national legislation to the provisions of the above Convention is being updated. Therefore, the suggestion of V.A. Mozgova and other possible suggestions will require the establishment of a range of legal facts that may lead to the removal, infibulation or any other operation for the total or partial removal of the labia majora, labia minora or clitoris in specially accredited health care institutions. Importantly, such a range should include the legal fact associated with congenital defects of the labia and post-traumatic defects (after childbirth, road accidents, criminal offences, etc.) $[4$, p. 76$]$.

Moreover, the statement of section 1 of the Art.121 of the CC of Ukraine as: "the intentional grievous bodily harm, that is, intentional bodily harm that is life-threatening at the time of infliction, or causing the loss of any body organ or its functions, genital mutilation ..." remains problematic. Apparently, intentional grievous bodily harm causes damage, which is manifested in one of its signs, and not vice versa. Based on the rules of the formal logic, at the statement of the loss of any body organ or its functions, etc., it is possible to assess the bodily harm as the grievous ones, but it is not the grievous bodily harm that causes the loss of any body organ or its functions.

\section{CONCLUSIONS}

1. Undoubtedly, the Council of Europe Convention on Preventing and Combating Violence against Women and Domestic Violence (ETS No. 210, Istanbul Convention) must be ratified by the Parliament of Ukraine properly. Ukraine must criminalize intentional illegal actions consisting in: 1) removal, infibulation or performing any other mutilation to the whole or any part of the labia majora, labia minora or clitoris; 2) coercing or inciting a woman to undergo the acts listed in the previous subparagraph; 3) inciting, coercing a girl to undergo acts listed in subparagraph 1.

2. The process of above criminalization must involve specialists in the field of practical medicine, as well as medical scientists in sexopathology, gynecology, oncogynecology, forensic medicine, and others, to avoid similar errors in the lawmaking, which occurred in amendments to the text of section 1 of the Art.121 of the CC of Ukraine. This is due to the fact that the lawmaker has actually distorted the content of the Convention by pointing to the genital mutilation (both male and female, as not indicated in the text) as a sign of the grievous bodily harm, but not as a consequence of illegal operation, resulting in mutilation of the genitalia. Therefore, we suggest the Rules should be supplemented with subparagraph 2.1.9 with the following statement: "Genital mutilation".

Under genital mutilation the consequences of the injury must be understood, whether or not they have led to loss of reproductive capacity, which correspond to at least one of the following: a) partial or total removal of the clitoris; b) partial or total removal of labia minora; c) partial or total removal of labia majora; d) partial or total removal of the penis; e) loss of the testicle; e) cicatrical deformity of the clitoris, or labia minora, or labia majora, or the penis, or the scrotum, the excision or diminishing of which is possible only by surgical intervention.

This criterion is not applicable: a) in cases of surgical intervention (in cicatrical deformation) prior the forensic medical examination to determine genital mutilation; $b$ ) for the abovementioned consequences after surgical interventions performed on medical reasons".

3. Section 1 of the Article 121 of the Criminal Code of Ukraine should be stated as follows: "infliction of intentional grievous bodily harm that is life-threatening at the time of infliction, or genital mutilation, the loss of any body organ or its functions, psychic illness or other health disorder, combined with persistent loss of capacity for work not less than one third, or termination of pregnancy or irreparable face defacement is liable for punishment.... And in the Rules, subparagraph 2.1.9 can be stated as follows: "Genital mutilation".

Genital mutilation is irreparable damage to the external genitalia, causing the loss of its natural appearance, whether it led or not to the loss of reproductive capacity. Under irreparable damage to the external genital organs it is necessary to understand such anatomical disintegration of tissues (lack of tissue part, cicatrical deformation, stamping-related deformation due to implantation of foreign bodies or substances, cicatricial changes), which severity does not decrease with time or under the influence of non-surgical means.

Genital mutilation involves the following irreparable damage: a) partial or total removal of the clitoris; b) partial or total removal of labia minora; c) partial or total removal of labia majora; d) partial or total removal of the penis; e) total removal of the scrotum; e) cicatrical deformation of the clitoris, or labia minora, or labia majora, or penis, or scrotum; e) deformation of the clitoris, or labia minora, or labia majora, or penis, or scrotum due to the implantation of foreign bodies or substances; g) stamping-related cicatricial changes in the clitoris, or labia minora, or labia majora, or penis, or scrotum. 
Of note, if at least one of the items listed in subpar a is anatomical disorder, occurred due to inadequate provision of medical care, the expert commission is entitled to consider this disorder as genital mutilation. Male circumcision, tattoo of the external genital organs does not refer to mutilation of the genital organs.

\section{REFERENCES}

1. Pravila sudebno-meditsinskogo opredeleniya stepeni tyazhesti telesnykh povrezhdeniy: Prikaz MOZ Ukrainy № 6 ot 17 yanvarya 1995 goda [Rules of forensic determination of the severity of bodily harm: Order of the Ministry of Health of Ukraine № 6 of January 17, 1995]. Rezhim dostupa:http://search.ligazakon.ua/l_doc2.nsf/link1/REG791. html. (Ru).

2. Pravila provedeniya sudebno-meditsinskikh ekspertiz (obsledovaniy) po povodu polovykh sostoyaniy v byuro sudebno-meditsinskoy ekspertizy: Prikaz MOZ Ukrainy № 6 ot 17 yanvarya 1995 goda [Rules for conducting forensic examinations (examinations) about sexual conditions in the Bureau of Forensic Medical Examination: Order of the Ministry of Health of Ukraine № 6 of January 17, 1995]. Rezhim dostupa: https://zakon. rada.gov.ua/laws/show/z0253-95. (Ru).

3. Konventsiya Rady Yevropy pro zapobihannya nasyl'stvu stosovno zhinok i domashn'omu nasyl'stvu ta borot'bu iz tsymy yavyshchamy: dovidnyk dlya chleniv parlamentu [Council of Europe Convention on the Prevention and Combating of Violence Against Women and Domestic Violence: Directory for Members of Parliament]. Kyyiv: Vydavnytstvo «K.I.S.», 2014. 108 p. (Ua).

4. Vyklyky dlya ukrayins'koho zakonodavstva, pov"yazaniz ratyfikatsiyeyu Konventsiyi Rady Yeuropy pro zapobihannya nasyl'stvu shchodo zhinok ta domashn'omu nasyl'stvu ta borot'bu z tsymy yavyshchamy: za rezul'tatamy kruhlykh stoliv: 16 chervnya 2016 roku, Verkhovna Rada Ukrayiny; 29 chervnya 2016 roku [Challenges for Ukrainian legislation related to the ratification of the Council of Europe Convention on the Prevention and Combating of Violence Against Women and Domestic Violence: Round Table Results: June 16, 2016]. KHNUVS. Kyyiv: FOP Moskalenko 0. M., 2016. 140 p. (Ua).

5. Pochemu v $00 \mathrm{~N}$ protestuyut protiv «zhenskogo obrezaniya»? [Why is the UN protesting female circumcision?]. Radio 00N. 2014. Rezhim dostupu: http://www.unmultimedia.org/radio/russian/archives/158341/. (Ru).

6. Pitel' Yu, Zolotarev I. Neotlozhnaya urologiya [Emergency Urology]. Moskva: Meditsina, 2001.319 p. (Ru).
7. Dmitriyeva 0, Fedchenko T, Danilyak T. Nekotoryye voprosy sudebnomeditsinskoy ekspertizy pri povrezhdeniyakh naruzhnykh polovykh organov muzhchin [Some questions of forensic medical examination for injuries of the male external genital organs]. Problemy ekspertizy v meditsine. 2009;33-1(09):14-17. (Ru).

8. Vozianov A, Gorpinchenko I. Seksologiya i andrologiya [Sexology and Andrology]. Kiyev: Arbis, 1997.880 p. (Ru).

9. Delyagin V, Nikanorov A. Diagnostika sostoyaniya organov moshonki (kliniko-ekhograficheskiye problemy): monografiya [Diagnosis of the state of the scrotum organs (clinical and echographic problems): monograph] Moskva: Altus, 1999.56 p. (Ru).

\section{ORCID and contributionship:}

Igor I. Mytrofanov - 0000-0002-1967-1985 A,C,D,F

Igor V. Lysenko - 0000-0003-1646-6369 ${ }^{B, C, D}$

Kateryna V. Hryn - 0000-0002-8759-3560 A,B,D

Mykola M. Ryabushko - 0000-0002-3617-4542 C,E,F

\section{Conflict of interest:}

The Authors declare no conflict of interest

\author{
CORRESPONDING AUTHOR \\ Kateryna V. Hryn \\ Department of Psychiatry, Narkology and Medical Psychology \\ Ukrainian Medical Stomatological Academy \\ Shevchenko 23 str., 36011, Poltava, Ukraine \\ tel: +380668126498 \\ e-mail: ekaterina.grin83@gmail.com
}

Received: 16.04 .2019

Accepted: 20.11.2019

A - Work concept and design, B - Data collection and analysis, C - Responsibility for statistical analysis, D-Writing the article, $\mathbf{E}$-Critical review, $\mathbf{F}$ - Final approval of the article 